\title{
Differences of Atocion lithuanicum from A. armeria and their hybrid (Sileneae, Caryophyllaceae) by ITS1-ITS2 sequences and secondary structure of their transcripts
}

\author{
Viktoriia O. MARTYNIUK ${ }^{1}$, Nataliia I. KARPENKO², Andrii S. TARIEIEV ${ }^{3}$, Igor Yu. KOSTIKOV ${ }^{1}$ \\ ${ }^{1}$ Department of Plant Biology, Educational and Scientific Centre "Institute of Biology and Medicine", Taras Shevchenko National \\ University of Kyiv \\ 64 Volodymyrska Str., Kyiv 01601, Ukraine \\ vikamartynuk@ukr.net \\ ${ }^{2}$ Research Laboratory of Biochemistry, Educational and Scientific Centre "Institute of Biology and Medicine", Taras Shevchenko \\ National University of Kyiv \\ 64 Volodymyrska Str., Kyiv 01601, Ukraine \\ karpenko_nataliia@ukr.net \\ ${ }^{3}$ Ukrainian Botanical Society \\ 2 Tereshchenkivska Str., Kyiv 01601, Ukraine \\ andrii.tarieiev@gmail.com
}

Martyniuk V.O., Karpenko N.I., Tarieiev A.S., Kostikov I.Yu. Differences of Atocion lithuanicum from A. armeria and their hybrid (Sileneae, Caryophyllaceae) by ITS1-ITS2 sequences and secondary structure of their transcripts. Ukr. Bot. J., 2018, 75(4): $322-334$.

Abstract. Many plant species have controversial taxonomical status, and clarification of that status is extremely important in cases of rare taxa when the need for their conservation is discussed. One of them is Atocion lithuanicum - an endemic taxon, treated either as separate species or synonym of $A$. armeria. The aim of the present study is to infer the taxonomic status of A. lithuanicum, using molecular phylogenetic analysis as well as ITS1 and ITS2 secondary structures comparison of those two taxa and their putative hybrid. The results of our phylogenetic analysis using Bayesian inference reveal that $A$. lithuanicum is not closely related to $A$. armeria, but instead is sister to $A$. compactum. However, phylogenetic relationships on the tree, which includes hybrids and taxa with SNPs, are not resolved well. In contrast, ITS1 secondary structure analysis allows us to distinguish clearly $A$. lithuanicum from $A$. armeria. The artificial F1 hybrid between these species has SNPs in all sites that differentiate parental forms and, by secondary structure, are located in the intermediate position between them. Thus, SNPs do not seem to be useful in phylogenetic analysis in this case. At the same time, ITS1 and ITS2 secondary structure reconstruction with SNP sites could be used as markers of hybridization events. Atocion lithuanicum is considered as separate species and could not be treated as synonym or variety of $A$. armeria.

Keywords: Atocion lithuanicum, endemism, hybridization, single nucleotide polymorphism, phylogeny

\section{Introduction}

Atocion lithuanicum (Zapał.) Tzvel. was originally described by H. Zapałowicz (1911) from Lithuanian and Volhynian Polissia as Silene lithuanica Zapał. Later it was included in Atocion Adans. by Tzvelev (2001). This species is distributed on poor sandy soils in Poland, Lithuania, Ukraine, and Belarus. In Lithuania and Ukraine, this species is considered as a rare Sarmatian endemic species and is therefore protected (Red data..., 2007; Andrienko et al., 2009).

(C) V.O. MARTYNIUK, N.I. KARPENKO, A.S. TARIEIEV, I.Yu. KOSTIKOV, 2018
Atocion lithuanicum is morphologically similar to A. armeria (L.) Raf., the latter taxon was described by Linnaeus as Silene armeria L. from England and France ("Anglia, Gallia") with its current native range throughout Southern and Central Europe (from the Pyrenees to the Balkans and northeastern Anatolia). Atocion armeria is also widely cultivated (Europe, Siberia, India, Far East, North America, Brazil) and sometimes naturalized (Coode, Cullen, 1967; Chater et al., 1993; Fedoronchuk, 1997). Both species have 2n $=24$ (Agapova et al., 1990; Chater et al., 1993). On the basis of its morphology, A. lithuanicum reportedly differs from $A$. armeria by narrower stem leaves with abaxially folded margins, slightly longer carpophores and capsules, 
petals with a less distinguished notch, and smaller seeds without papillae (Klokov, 1952; Fedoronchuk, 1997; Martynyuk et al., 2015).

Due to the morphological similarities, identical chromosome numbers and overlapping ranges of A. lithuanicum and A. armeria, A. lithuanicum has been variously treated taxonomically since the time of its description. At first, A. lithuanicum was considered as a separate endemic species, but still closely related to A. armeria (Klokov, 1952; Fedoronchuk, 1997; Mosyakin, Fedoronchuk, 1999; Andrienko et al., 2009). Another point of view is the recognition of that taxon as a variety of $A$. armeria $[A$. armeria (L.) Raf. var. lithuanicum (Zapał.) Niketić \& Stevanović (= Silene armeria var. lithuanica (Zapał.) Graebner \& Graebner fil.] (Niketić et al., 2007). According to Chater et al. (1993) and other recent publications (Frajman et al., 2009b, 2013), A. lithuanicum should be regarded as a mere heterotypic synonym of $A$. armeria.

In order to solve similar taxonomical issues, molecular genetic methods are widely used, in particular, ITS2 (ribosomal DNA) secondary structure analysis. Molecular data on A. lithuanicum have never been published, while ITS1-5.8S-ITS2 sequences of seven Atocion species, including three $r$ DNA sequences of $A$. armeria, are deposited in GenBank. It is considered that in accordance with the change type of ITS2 secondary structure (first of all, the presence and number of compensatory and hemicompensatory base changes - $\mathrm{CBC}$ and $\mathrm{hCBC}$ ) the level of reproductive isolation between taxa could be estimated (Coleman, Mai, 1997; Coleman, 2000; Ruhl et al., 2009) and, respectively, the taxonomic status of operational taxonomic units (OTU) could be specified (Müller et al., 2007). Moreover, ITS1 secondary structure may as well be used in such analysis, which has already been shown by us on $A$. hypanicum (Klokov) Tzvelev (Martynyuk et al., 2014).

One of the problems that arises both during molecular phylogenetic trees reconstruction and $r$ DNA transcripts secondary structure modeling lays in ambiguous sites in sequences of many plant species, which can be interpreted sometimes as single nucleotide polymorphisms (SNP) (Gupta et al., 2001) or can be treated as a consequence of other circumstances i.e. polymerase errors during PCR or sequencing, low signal misinterpretation etc. (Clarke et al., 2001; Kunin et al., 2011). In particular, $13 r$ DNA Atocion sequences from GenBank out of 18 contain ambiguous positions which can be probably treated as SNPs, as well as all

Укр. бот. журн., 2018, 75(4) $r$ DNA sequences of A. armeria (Oxelman, Lidén, 1995; Frajman et al., 2009b).

The presence of SNPs is usually considered as a consequence of intragenomic polymorphism caused by the presence of multiple $r$ DNA copies in the genome at which copies with different alleles have emerged as a result of either the independent evolution (Bailey et al., 2003; Drábková et al., 2009) or hybridization between different populations and even species (Castro et al., 2013; Hodač et al., 2014). During the reconstruction of molecular phylogenies, sites with SNP are usually deleted, which decreases the resolution of phylogenetic trees (Frajman et al., 2009a). Considering SNPs as the consequence of hybridization events (but not an independent evolution of different copies), comparative analysis of ITS secondary structures of each allele would allow inferring phylogenetic relationships for taxa which have sequences with SNPs. In addition, such analysis would possibly reveal parental forms of the supposedly hybrid taxa. Thus, the solution of the SNP issue (a result of the independent evolution or hybridization) could be found after artificial hybridization experiments.

The aim of the present study is to test the hypothesis of the separate species status of Atocion lithuanicum using nuclear $r$ DNA sequences. In particular, we compared the sequences of ITS1-5.8S-ITS2 of A. lithuanicum with other species of Atocion. We also examined the differences of ITS1 and ITS2 secondary structure between the morphologically similar A. lithuanicum and $A$. armeria as well as between $A$. lithuanicum and its hybrids with $A$. armeria, including SNP analysis.

\section{Materials and methods}

The specimen of Atocion lithuanicum was collected on the territory of Ukrainian Polissia (Hoshcha district, Rivne Region) in a psamophytic plant community near Krynychky village. Leaves of this sample were used for DNA extraction. Later a few specimens from this population were transferred to a greenhouse for further hybridization tests with $A$. armeria .

Herbarium specimens and seeds of Atocion armeria were collected in Kislovodsk (Stavropol Krai, Russian Federation), where plants were cultivated as ornamentals. Plants were grown from seeds in the greenhouse. On the stage of seedlings, leaf fragments were collected for DNA isolation, and during the flowering stage hybridization with $A$. lithuanicum was conducted.

Specimens of both species are in full compliance with morphological descriptions provided in the literature 
(Zapałowicz, 1911; Klokov, 1952; Coode, Collen, 1967; Chater et al., 1993).

Crossing experiments. Hybridization was carried out according to the scheme: 9 Atocion lithuanicum $\times$ A. armeria $\bigcirc$. Parental lines served as control. Plants of A. lithuanicum were isolated from A. armeria. Flowers of $A$. lithuanicum were emasculated while still in bud to prevent self-pollination. The calyx was carefully slitten and the immature anthers pulled out. On the third day after emasculation, stigmas became receptive. Pollination was conducted by rubbing mature anthers of A. armeria on the stigmas of $A$. lithuanicum emasculated flowers. Seeds from crosses were collected, sown and the seedlings grown on. Leaves of hybrid plants were used for DNA isolation.

DNA extraction, PCR, and sequencing. Total genomic DNA was extracted from leaf fragments of Atocion lithuanicum, $A$. armeria and $P$ A. lithuanicum $\times A$. armeria $^{\top}$ (two repetitions) using the modified CTAB-method (Doyle, Doyle, 1990; Tarieiev et al., 2011). PCR was performed using universal primers ITS1-ITS4 and ITS4-ITS5 according to White (1990). Sequencing of amplified fragments was performed using ITS4 primer (for A. lithuanicum - both ITS1 and ITS4) at Macrogen Inc. (http://www.macrogen.com, Netherlands). Sequences editing and SNP detection were carried out using BioEdit (Hall, 1999).

Annotation of sequences. ITS2 annotation was carried out by secondary structure modeling of $5.8 \mathrm{~S}$ $r$ RNA terminal fragment and complementary starting fragment of 26S $r$ RNA (which forms helix B9 of $r$ RNA according to Caisová et al., 2013) according to Gottschling's model (Gottschling, Plötner, 2004) using Mfold (Zuker, 2003). ITS1 annotation was performed according to $A$. compactum (Fisch. ex Hornem.) Tzvel. annotation (NCBI accession code FJ384030), which was elaborated by Frajman et al. (2009b).

Phylogenetic analysis. Phylogenetic analysis was performed for the set of Atocion and related Viscaria Bernh. ITS sequences (Table 1) (including Silene paucifolia Ledeb. as the outgroup) were used for reconstruction of phylogenic trees of two types. For the first type sequences without or only with one SNP (that were treated as two sequences with different alleles) were used. The second phylogenetic reconstruction was performed for the sequences with ambiguous positions that can be treated as SNP sites. Before analysis, the set was aligned using ClustalW (Thompson et al., 1994) and converted to NEXUS format. The next stage was searching for the optimal phylogenetic model by
Modeltest 3.7 (Posada, Crandall, 1998), incorporated in PAUP version 4.0a150. Phylogenetic trees were reconstructed using MrBayes 3.2 (Ronquist et al., 2012) with GTR $+\mathrm{I}+\mathrm{G}$ phylogenetic model (Tavaré, 1986) and following settings recommended for the particular settings: nucleotide model -4 by 4 , Nst -6 , gamma distribution. Number of iterations - 20000, samplefreq $=100$ printfreq $=100$ diagnfreq $=1000$. The rest of settings were default and main part were done using Markov chain Monte Carlo (MCMC) (Hastings, 1970; Yang, Rannala, 1997; Mau et al., 1999).

Modeling of ITS1 and ITS2 secondary structures. ITS1 and ITS2 were reconstructed using mFold (Zuker, 2003), each helix was modeled separately. For ITS1, the third helix was firstly found by universal for the vascular plants conservative motif of Liu and Schardl (1994). The first, second and the fourth helices were detected in accordance to the criteria proposed for Boraginales (i.e. the presence of A-rich regions as spacers between helices) (Gottschling et al., 2001). ITS2 models were obtained according to currently used criteria for its folding (i.e. the presence of four helices with helix 3 as the longest one, a pyrimidine-pyrimidine mismatch in helix 2 and a NRTGGT motif on the 5' side of helix 3) (Coleman, Mai, 1997; Coleman, 2007). ITS1 and ITS2 secondary structures comparison was conducted with A. lithuanicum, A. armeria, and their hybrid.

\section{Results}

Sequence analyses. ITS1-5.8S-ITS2 rDNA sequence of Atocion lithuanicum is unique and does not have any sites with SNP. It is similar, but not identical to $A$. lerchenfeldianum (Baumg.) M. Popp (FJ384033, identity 98.2\%), A. armeria (FJ384026, 97.9\%), and A. compactum (FJ384031, 97.9\%).

The sequence of cultivated $A$. armeria is unique as well. It is most similar (100\% query cover) to sequences A. armeria from Slovenia (FJ384027, 98.6\% of identity) and A. lerchenfeldianum (FJ384033, 98.29\%). It differs from other nrDNA sequences of $A$. armeria deposited in NCBI in SNP absence.

Thus, both sequenced parental forms (A. lithuanicum and $A$. armeria), used in hybridization experiment, do not contain any SNP in ITS1 and ITS2; thereby in terms of classical genetics (King et al., 2007) they could be named as True Breeding Organisms (TBO). The sequence of $A$. lithuanicum differs from TBO $A$. armeria in 13 sites (97.98\% of similarity) (Table 2). 
Table 1. GenBank accession numbers and voucher data for specimens used for phylogenetic analysis

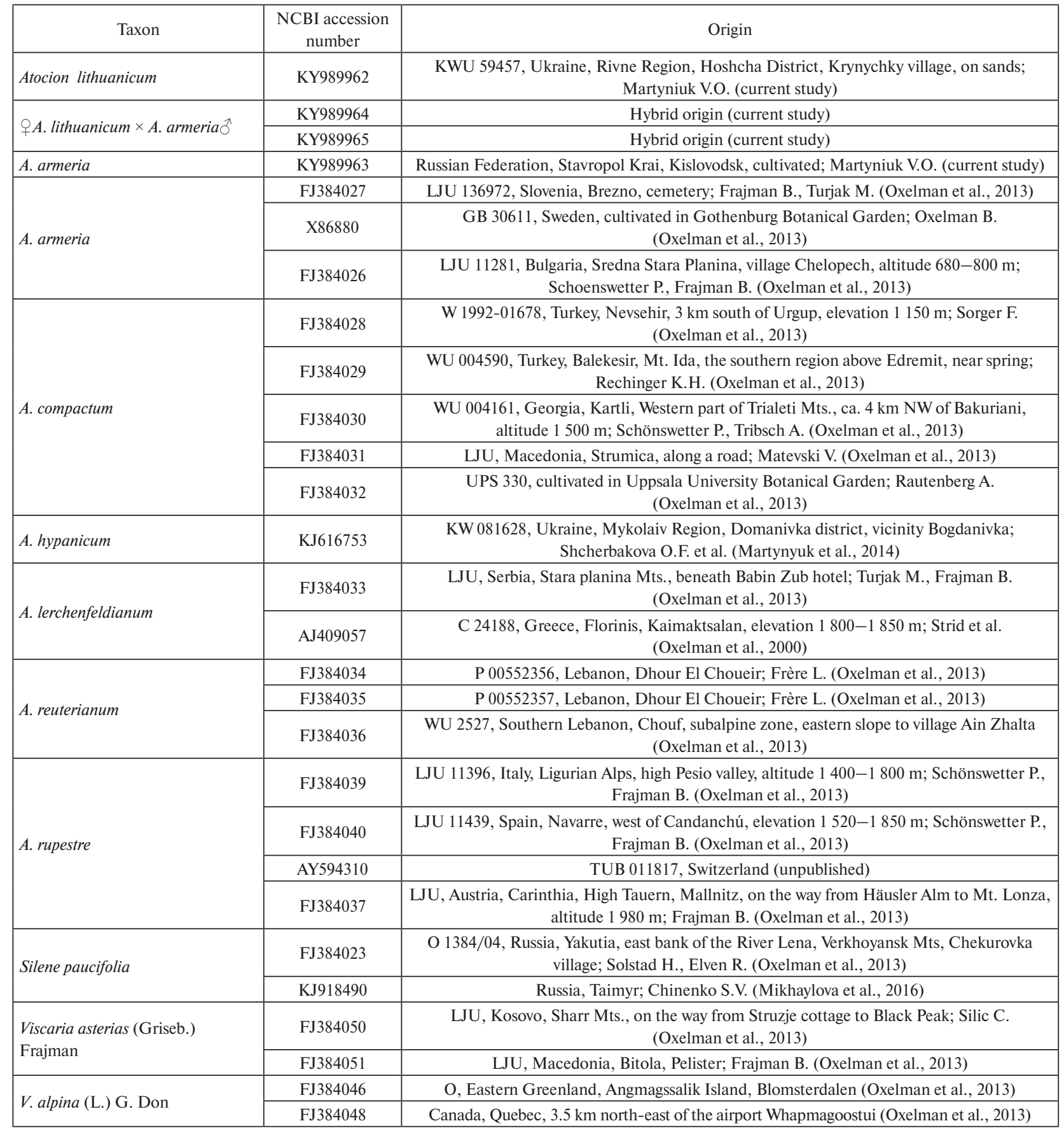

Table 2. Variable sites in sequences of Atocion lithuanicum, A. armeria (True Breeding Organisms), and hybrids between them

\begin{tabular}{|c|c|c|c|c|c|c|c|c|c|c|c|c|c|c|}
\hline \multirow{2}{*}{ Taxon } & \multirow{2}{*}{ Accession number } & \multicolumn{11}{|c|}{ ITS1 } & \multirow{2}{*}{$\begin{array}{c}5.8 \mathrm{~S} \\
133\end{array}$} & \multirow{2}{*}{$\frac{\text { ITS2 }}{172}$} \\
\hline & & 13 & 42 & 58 & 65 & 66 & 74 & 75 & 77 & 99 & 119 & 123 & & \\
\hline Atocion lithuanicum & KY989962 & $\mathrm{T}$ & A & $\mathrm{C}$ & $\mathrm{T}$ & G & $\mathrm{C}$ & $\mathrm{C}$ & $\mathrm{C}$ & G & $\mathrm{C}$ & $\mathrm{C}$ & $\mathrm{C}$ & $\mathrm{C}$ \\
\hline A. armeria & KY989963 & $\mathrm{C}$ & $\mathrm{C}$ & $\mathrm{T}$ & $\mathrm{C}$ & $\mathrm{A}$ & $\mathrm{T}$ & $\mathrm{G}$ & $\mathrm{T}$ & $\mathrm{T}$ & $\mathrm{T}$ & $\mathrm{T}$ & $\mathrm{T}$ & $\mathrm{T}$ \\
\hline \multirow{2}{*}{$\begin{array}{l}\text { A. lithuanicum } \\
\times \text { A.armeria }\end{array}$} & KY989964 & $\mathrm{Y}$ & $M$ & $\mathrm{Y}$ & $\mathrm{Y}$ & $\mathrm{R}$ & $\mathrm{Y}$ & $\mathrm{S}$ & $\mathrm{Y}$ & $\mathrm{K}$ & $\mathrm{Y}$ & $\mathrm{Y}$ & $\mathrm{Y}$ & $\mathrm{Y}$ \\
\hline & KY989965 & $\mathrm{Y}$ & $M$ & $\mathrm{Y}$ & $\mathrm{Y}$ & $\mathrm{R}$ & $\mathrm{Y}$ & $\mathrm{S}$ & $\mathrm{Y}$ & $\mathrm{K}$ & $\mathrm{Y}$ & $\mathrm{Y}$ & $\mathrm{Y}$ & $\mathrm{Y}$ \\
\hline
\end{tabular}

Укр. бот. журн., 2018, 75(4) 
Both sequences of $A$. lithuanicum $\times A$. armeria are identical. It is clear from Fig. 1 that sequences of hybrids have SNPs, which are a combination of parental alleles in all 13 sites that differentiate parental TBO A. lithuanicum from $A$. armeria. Interestingly, according to the BLAST-search $A$. lithuanicum $\times A$. armeria hybrids are most similar to $A$. armeria sequences from Bulgaria (FJ384026) and Slovenia (FJ384027), and A. lerchenfeldianum from Serbia (FJ384033), which contain from 1 up to 14 SNP sites.

Phylogenetic analysis. Atocion and Viscaria form monophyletic groups with strong support and have sister relationship between them (Figs 1, 2, 3).

Concerning Atocion (Fig. 2), A. rupestre is the basal species, while the other taxa form two subclades. The first one includes $A$. lithuanicum and $A$. compactum from Turkey, Republic of Macedonia, and the Ukrainian cultivar. The second subclade includes $A$. armeria and samples of $A$. lerchenfeldianum from Greece and Serbia. Atocion lithuanicum is sister to A. compactum, but with low posterior probability.

As it is clear from a tree in Fig. 3, monophyletic single-species clades are formed only by sequences that do not have SNP or contain only small amount of them. For instance, well-supported single-species clades are formed by $A$. rupestre (0-6 SNPs), A. reuterianum (3-4 SNPs), and $A$. lerchenfeldianum (1 SNP). Taxa with a higher number of SNPs (from 7 up to 14: FJ384026, FJ384027, FJ384028), similarly to A. lithuanicum $\times$ A. armeria hybrid, do not form proper clades.

Thus, addition of sequences with SNPs in the dataset leads to the formation of the nodes that collapse in the tree. However, SNPs may carry valuable information on hybrid taxa and taxa of hybrid origin. In such cases, analysis of ITS1 and ITS2 secondary structures will help to distinguish taxa, even hybrids.

ITS1 and ITS2 secondary structures. Differences between Atocion lithuanicum and TBO of A. armeria become more evident when comparing ITS1 and ITS2 transcript secondary structure.

The highest amount of changes (9) can be observed in the first and second helices of ITS1, which are shown in Fig. 4. The most important difference between A. lithuanicum and A. armeria is CBC (helix 1), caused by changes at sites $66 / 74(\mathrm{G}-\mathrm{C} \rightarrow \mathrm{A}-\mathrm{U})$. Besides, two changes at sites 65, 75 (helix 1) and 99 (helix 2) cause structural changes in ITS1 of A. lithuanicum and A. armeria TBO. Other four base changes (sites 58, 77, $119,123)$ represent $\mathrm{hCBC}$, additionally differentiating these OTU. There are also two changes in single- stranded fragments (loops) at sites 13 and 42 that are considered as less taxonomically ponderable.

ITS2 secondary structure models of TBO A. lithuanicum and A. armeria are similar (according to Fig. 5). The only change in the third helix that differentiates these OTU $(172 . \mathrm{C} \rightarrow \mathrm{U})$ is located at the 3 '-side of the subbasal loop and does not cause any structural changes, $\mathrm{CBC}$ or hCBC.

Atocion lithuanicum and A. armeria also differ in one substitution in 5.8S $r \mathrm{DNA}$, which is considered as highly conservative. It is hCBC (G-C in A. lithuanicum, G-U in A. armeria) located at the 133rd site of helix F (according to the terminology of Vaughn et al., 1984), which represents the only variable region of the gene.

Atocion lithuanicum $\times$ A . armeria hybrids in ITS1, ITS2, and 5.8S sites, that differentiate parental species, have SNP that are combinations of parental alleles. In accordance, secondary structures of hybrids have both variants and represent a kind of "intermediate" model between $A$. lithuanicum and A. armeria.

\section{Discussion}

According to the results of BLAST-search, A. lithuanicum is similar to three other Atocion sequences, i.e. A. lerchenfeldianum (FJ384033), A. armeria (FJ384026) and A. compactum (FJ384031), but these results could not specify the taxonomical status of the taxon investigated in the present paper. However, phylogenetic analysis of TBO has shown that $A$. lithuanicum is not closely related to $A$. armeria, being sister to the $A$. compactum clade. Probably $A$. lithuanicum was thought to be close to $A$. armeria because of the overlapping ranges, while ranges of $A$. lithuanicum and $A$. compactum are geographically isolated. Nonetheless, phylogenetic relationships of $A$. lithuanicum on reconstructions that include SNP, are not clearly resolved: A. lithuanicum seems to be a separate taxon, as well as artificial hybrids (A. lithuanicum $\times$ A. armeria) and other sequences with numerous ambiguous sites.

During the recent few years, the prediction of ITS2 secondary structure and its comparative analysis have become popular for various taxonomic studies (Goertzen et al., 2003; Wiemers et al., 2009; Merget, Wolf, 2010), especially in connection with the CBC species concept introduced by Coleman (2000). This concept claims that if two taxa differ by their CBC in ITS2 secondary structure, they are sexually incompatible, and therefore belong to different species or even higher taxonomic ranks (Coleman, 2000, 2007; Müller et al., 2007; Ruhl et al., 2009). From this point

Ukr. Bot. J., 2018, 75(4) 

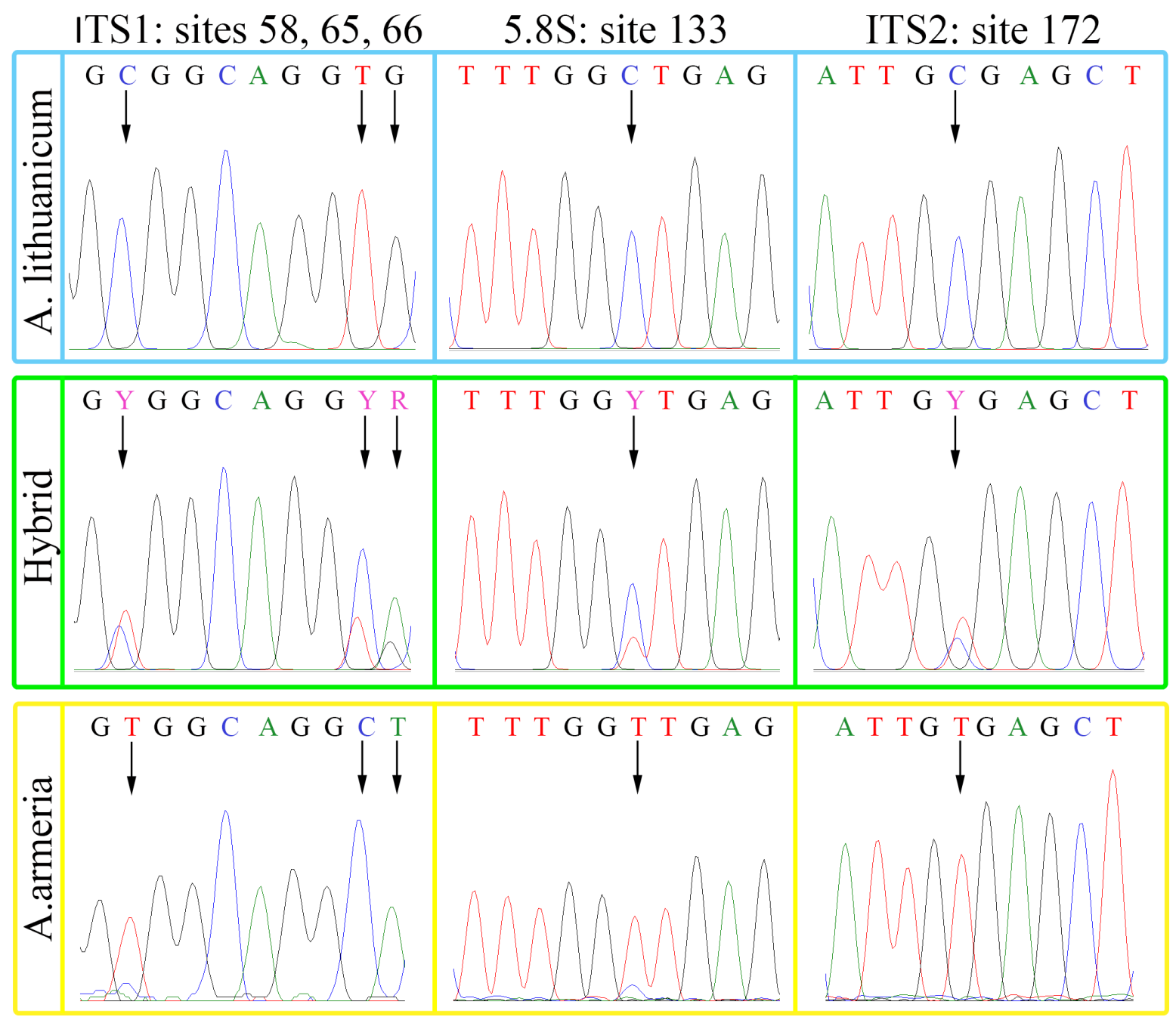

Fig. 1. Examples of chromatogram fragments that demonstrate the presence of SNP in hybrids Atocion lithuanicum $\times$ A. armeria at sites that differentiate the parental forms (A. lithuanicum and A. armeria,True Breeding Organisms) 


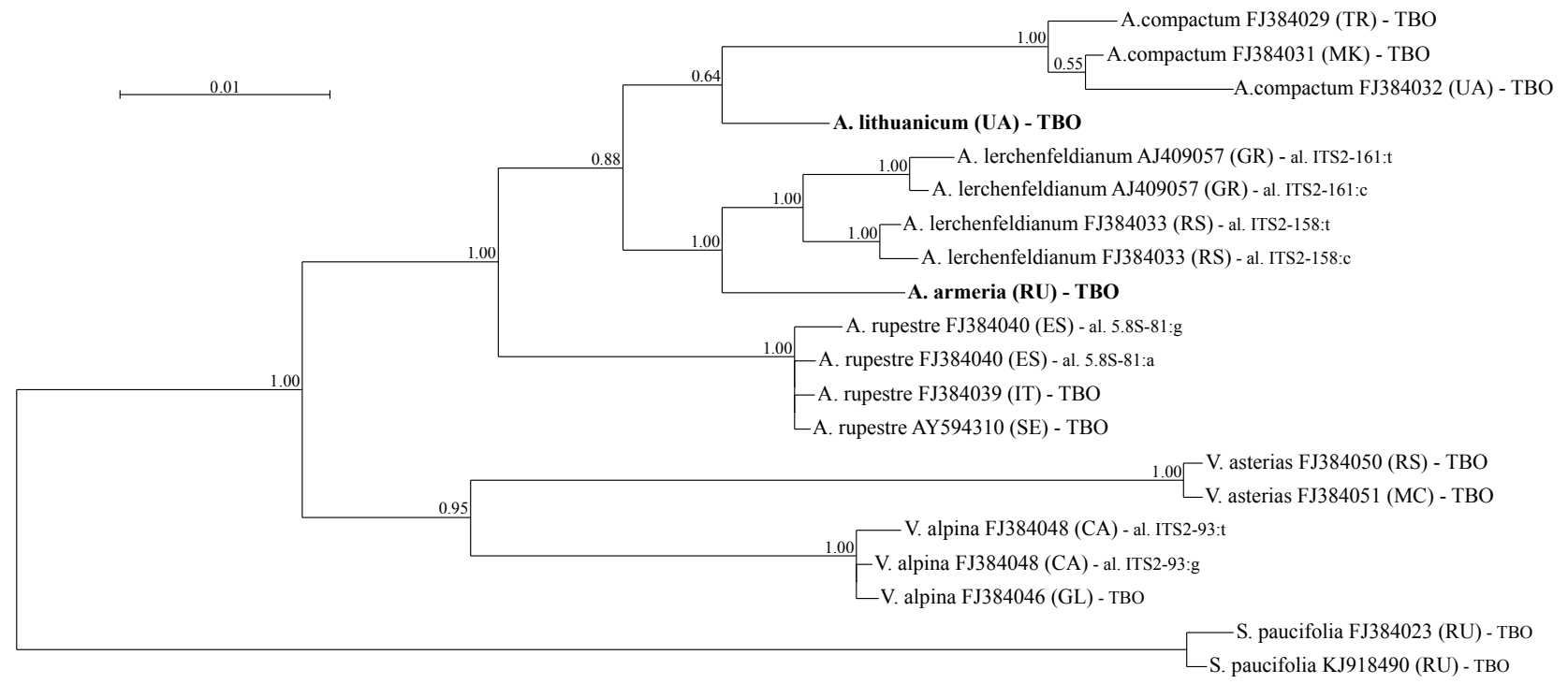

Fig. 2. Bayesian phylogenetic tree (obtained with GTR $+\mathrm{I}+\mathrm{G}$ nucleotide substitution model) of Atocion and Viscaria ITS15.8S-ITS2 sequences (True Breeding Organisms and taxa with a low number of ambiguous sites). Numbers next to the taxa correspond to accession identifiers in Table 1. The geographic origin of sequences is indicated with country/area codes (CA, Canada; ES, Spain; GL, Greenland; GR, Greece; IT, Italy; MK, Macedonia; RS, Serbia; RU, Russia; SE, Sweden; TR, Turkey; UA, Ukraine). Sequences with ambiguous sites are divided into two alleles (al.) with indication on the sequence (ITS2 or 5.8S), site number, and one of the possible nucleotides. Numbers below branches indicate posterior probability obtained from Bayesian analyses

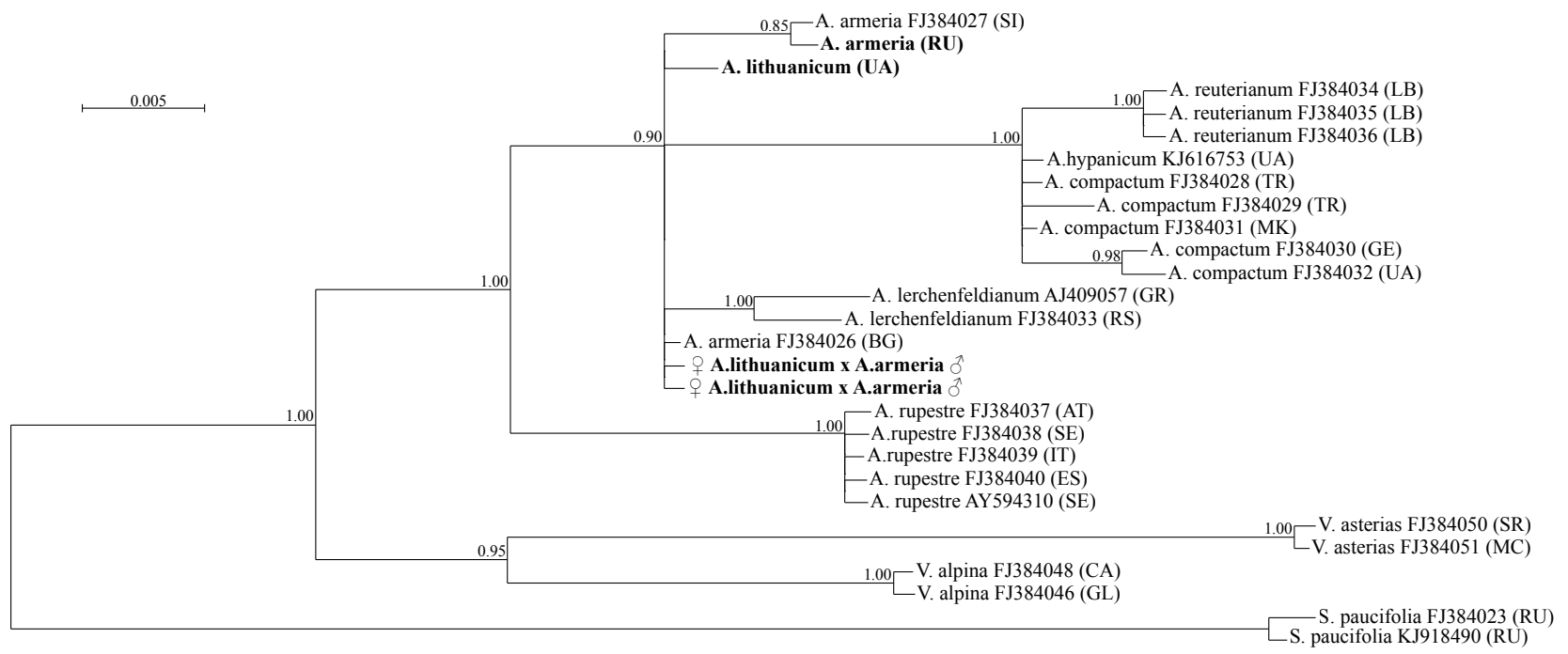

Fig. 3. Bayesian phylogenetic tree (obtained with $\mathrm{GTR}+\mathrm{I}+\mathrm{G}$ nucleotide substitution model) of Atocion and Viscaria ITS15.8S-ITS2 sequences that includes sequences with ambiguous positions and SNP sites. Numbers next to the taxa correspond to accession identifiers in Table 1. The geographic origin of sequences is indicated with country/area codes (AT, Austria, BG, Bulgaria; CA, Canada; ES, Spain; GE, Georgia; GL, Greenland; GR, Greece; IT, Italy; LB, Lebanon; MK, Macedonia; RS, Serbia; RU, Russia; SE, Sweden; SI, Slovenia; TR, Turkey; UA, Ukraine). Numbers below branches indicate posterior probability obtained from Bayesian analyses 


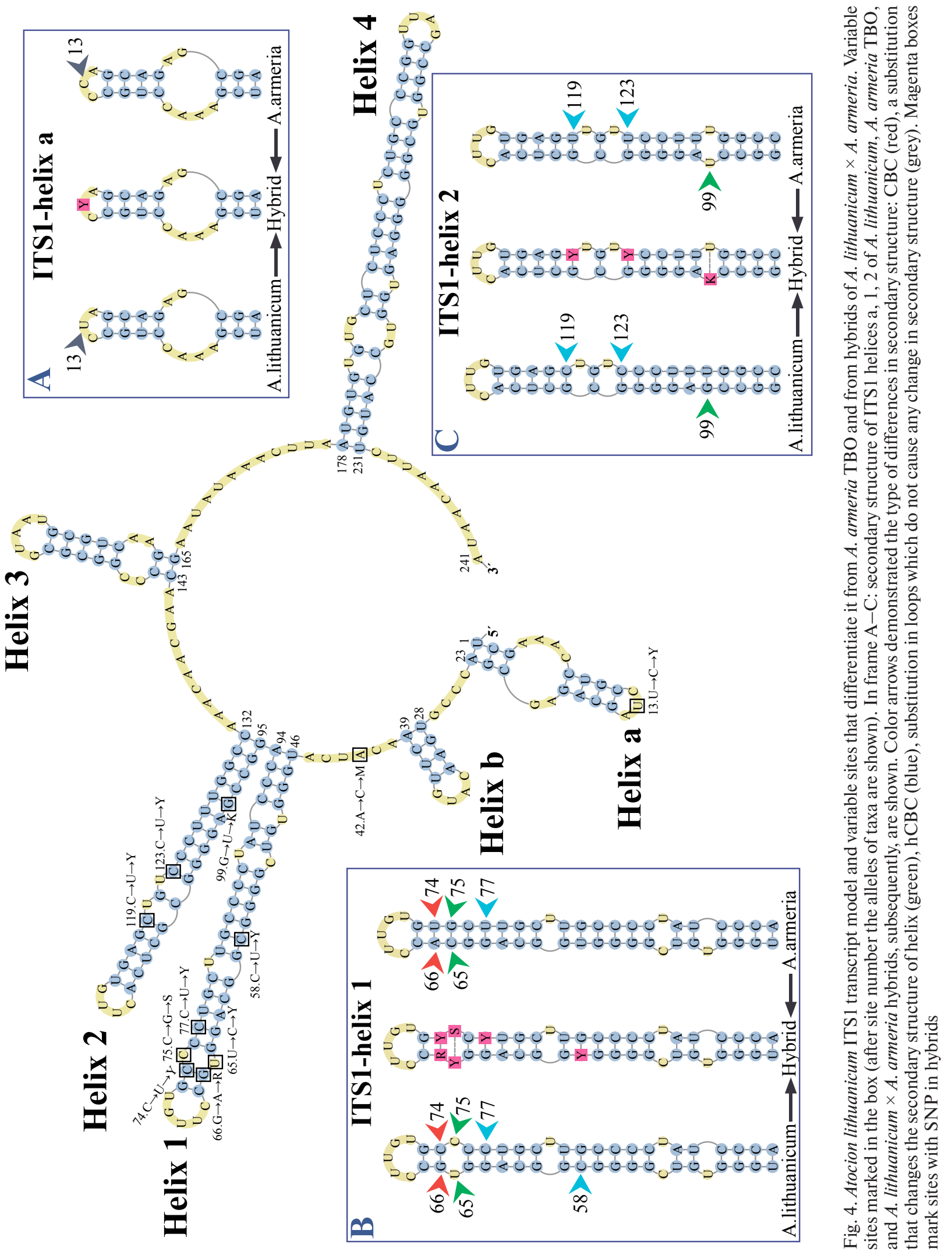

Укр. бот. журн., 2018, 75(4) 


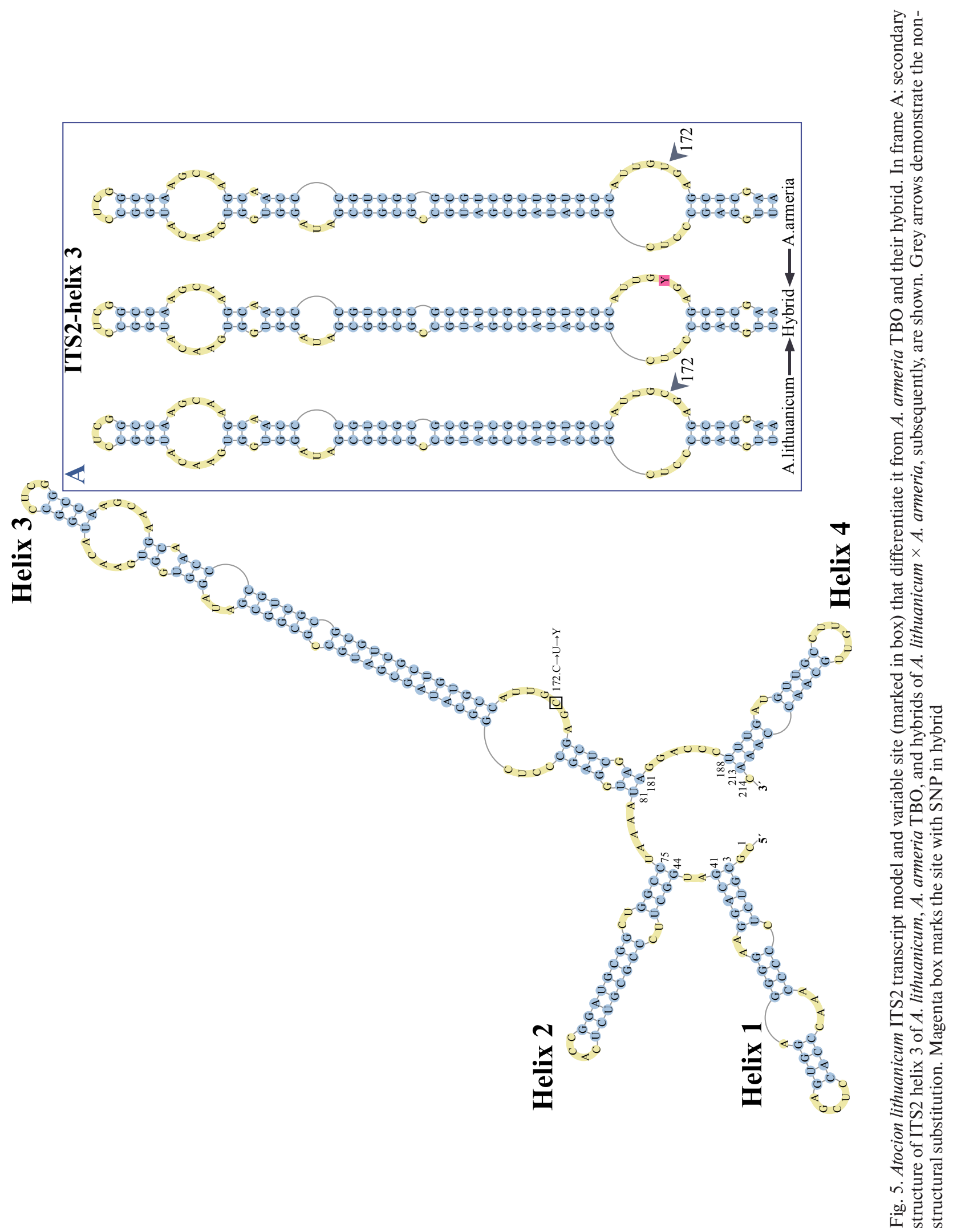


of view, the analysis of ITS2 secondary structure of $A$. lithuanicum in comparison with $A$. armeria may be useful taxonomically. But it was found that $A$. lithuanicum and A. armeria do not differ in their ITS2 secondary structure by any $\mathrm{CBC}$. As we have shown by our hybridization experiment, they are capable of sexual crossing, which corresponds to Coleman's concept. Whereas these species differ only by one non-structural substitution, ITS2 has failed to differentiate them.

Thus, the comparative analysis of ITS1 secondary structures has been conducted, which, according to literature data (Gottschling et al., 2001; Gottschling, Plötner, 2004; Moysiyenko et al., 2014), increases the number of characteristics and can be useful for taxonomic studies. The results of comparative analysis have shown that $A$. lithuanicum and $A$. armeria differ in one non-structural and two structural substitutions, four hCBC, and even one CBC. Thereby ITS1 secondary structure is a clearly better tool for the investigated taxa than ITS2 and can distinguish them as two separate species. In spite of A. lithuanicum and A. armeria having CBC in ITS1, they are sexually compatible. This fact leads to the conclusion that Coleman's concept is less conservative and not suitable for ITS1.

Apart from that, in non-cloned sequences of $r \mathrm{DNA}$ SNPs are usually interpreted as the consequence of intragenomic polymorphism, which can be caused by repetitiveness in the genome (Drábková et al., 2009; Bailey et al., 2003). One of the reasons of intragenomic polymorphisms, which can be resulted in the SNP presence, is interpopulational and interspecific hybridization (Castro et al., 2013; Hodač et al., 2014). Resulting from that hybridization, there are three pathways of ribosomal DNA evolution (Hřibová et al., 2011). According to the first evolutionary scenario, the parental sequences remain conserved and do not interact in hybrids, thus evolving independently; the second pathway consists in recombination of parental loci resulting in chimerical ITS sequences; and the third scenario is characterized by homogenization of $r \mathrm{DNA}$ because of a dominance of one parental sequence (Hřibová et al., 2011). Thus, the first type of evolution that occurs in different plant species, including Silene (Popp, Oxelman, 2001) can be observed as the appearance of polymorphic SNP sites. Therefore, in some cases, SNPs could be markers of hybridization. This statement is confirmed by the fact that the hybrid of $A$. lithuanicum and A. armeria has SNPs in all sites, which are different in parental sequences.
Besides, sequences of $A$. armeria from Genbank (FJ384036, FJ384027, X86880) are not identical and contain a number of SNPs. The most similar to A. armeria TBO is another cultivar of $A$. armeria, but from Sweden (X86880), which differs only by one SNP. Sequences from the native range (Slovenia and Bulgaria) has much more SNPs -9 and 14, respectively. Probably these taxa are of the hybrid origin as the result of hybridization with other Atocion species occurring in the Balkans.

Moreover, A. lithuanicum differs from A. armeria morphologically: it has exclusively erect stems furcated in their upper parts, a rosette of thickened leaves at the stem base, narrower leaves (2-15 vs. $10-30 \mathrm{~mm}$ ) with adaxially folded margins, longer carpophores (8-10 vs. $6.5-8 \mathrm{~mm})$ and capsules $(6.5-8$ vs. $8-10 \mathrm{~mm})$, and also petals with less distinguished notch (Zapałowicz, 1911; Klokov, 1952; Fedoronchuk, 1997). There are also distinctions in ultrastructure of pollen grains: the diameter of pores (3.04-5.22 $\mu \mathrm{m}$ in A. lithuanicum vs. $2.62-4.15 \mu \mathrm{m}$ in $A$. armeria), microechinate number of the pore (11-20 (25) vs. 7-14) and the shape of spinules on exine (acute or obtuse) (Martynyuk et al., 2015). Distinctions in seed morphology are associated with the seed size $(350-570 \times 450-630 \mu \mathrm{m}$ for $A$. lithuanicum vs. $480-670 \times 600-800 \mu \mathrm{m}$ for $A$. armeria), dimensions of exotesta cells in the distal row of the lateral surface $(69-160 \times 13-28.6$ vs. $95.6-202.7 \times 7.8-40.5 \mu \mathrm{m})$, the number of anticlinal wall teeth (15-24 vs 19-29) and absent or scarce subtle papilla on exotesta periclinal walls in A. lithuanicum as compared to clearly distinct ones in A. armeria (Martynyuk et al., 2015).

\section{Conclusions}

According to our molecular phylogenetic analysis, secondary structure models comparison, and also morphological characteristics described in the literature, A. lithuanicum is better treated as a separate species, not a variety or synonym of $A$. armeria. Results of our hybridization experiment suggest that parental alleles are both inherited in F1 hybrid, therefore SNP in ITS1-5.8S-ITS2 secondary structures could be used as markers of hybridization events.

\section{REFERENCES}

Agapova N.D., Arkharova K.B., Vakhtina L.I., Zemskova E.A., Tarvis L.V. Numeri chromosomatum Magnoliophytorum florae URSS: Aceraceae-Menyanthaceae. Ed. A. Takhtajan. Leningrad: Nauka, 1990, 509 рр. [Агапова Н.Д., Архарова К.Б., Вахтина Л.И., Земскова Е.А., Тарвис Л.Е. Числа хромосом иветковых рас- 
тений флоры СССР: Семейства Aceraceae-Menyanthaсеае. Ред. А. Тахтаджян. Л.: Наука, 1990, 509 с.].

Andrienko T.L., Pryadko O.I., Fedoronchuk M.M. Silene lithuanica. In: Chervona knyha Ukrainy. Roslynnyi svit (Red Data Book of Ukraine. Plant Kingdom). Ed. Ya.P. Didukh. Kyiv: Globalconsulting, 2009, p. 404. [Андрієнко Т.Л., Прядко О.І., Федорончук М.M. Silene lithuanica. В кн.: Червона книга України. Рослинний cвim. Ред. Я.П. Дідух. Київ: Глобалконсалтинг, 2009, c. 404].

Bailey C.D., Carr T.G., Harris S.A., Hughes C.E. Characterization of angiosperm nrDNA polymorphism, paralogy, and pseudogenes. Mol. Phylogenet. Evol., 2003, 29: 435455. https://doi.org/10.1016/j.ympev.2003.08.021

Caisová L., Marin B., Melkonian M. A consensus secondary structure of ITS2 in the Chlorophyta identified by phylogenetic reconstruction. Protist, 2013, 164: 482-496. https://doi.org/10.1016/j.protis.2013.04.005

Castro O., Maio A., García J.A.L., Piacenti D., VázquezTorres M., Luca P. Plastid DNA sequencing and nuclear SNP genotyping help resolve the puzzle of Central American Platanus. Ann. Bot., 2013, 112(3): 589-602. https:// doi.org/10.1093/aob/mct134

Chater A.O., Walters S.M., Akeroyd J.R. Silene. In: Flora Europaea. Eds T.G. Tutin, N.A. Burges, A.O. Chater, J.R. Edmondson, V.H. Heywood, D.M. Moore, D.H. Valentine, S.M. Walters, D.A. Webb. Cambridge: Cambridge Univ. Press, 1993, vol. 1, pp. 191-211.

Clarke L.A., Rebelo C.S., Gonçalves J., Boavida M.G., Jordan P. PCR amplification introduces errors into mononucleotide and dinucleotide repeat sequences. Molecular Pathology, 2001, 54: 351-353.

Coleman A.W. The significance of a coincidence between evolutionary landmarks found in mating affinity and a DNA sequence. Protist, 2000, 151: 1-9. https://doi. org/10.1078/1434-4610-00002

Coleman A.W. Pan-eukaryote ITS2 homologies revealed by RNA secondary structure. Nucleic Acids Res., 2007, 53(1): 3322-3329. https://doi.org/10.1093/nar/gkm233

Coleman A.W., Mai J.C. Ribosomal DNA ITS-1 and ITS-2 sequence comparisons as a tool for predicting genetic relatedness. J. Mol. Evol., 1997, 45: 168-177.

Coode M.J.E., Collen J. Silene. In: Flora of Turkey and the East Aegean Islands. Ed. P.H. Davis. Edinburgh: Edinburgh Univ. Press, 1967, vol. 2, pp. 179-242.

Doyle J.J., Doyle J.L. Isolation of plant DNA from fresh tissue. Focus, 1990, 12: 13-15.

Drábková L.Z., Kirschner J., Štěpánek J., Záveský L., Vlček Č. Analysis of nrDNA polymorphism in closely related diploid sexual, tetraploid sexual and polyploid agamospermous species. Pl. Syst. Evol., 2009, 278: 67-85. https://doi.org/10.1007/s00606-008-0134-8.

Fedoronchuk M.M. Ukr. Bot. J., 1997, 54(6): 557-564. [Федорончук M.M. Silene L. sensu lato в Україні: огляд роду Silene sensu stricto (Caryophyllaceae). Укp. бот. журн., 1997, 54(6): 557-564].

Frajman B., Eggens F., Oxelman B. Hybrid origins and homoploid reticulate evolution within Heliosperma (Sileneae, Caryophyllaceae) - a multigene phylogenetic approach with relative dating. Syst. Biol., 2009a, 58(3): 328-345. https://doi.org/10.1093/sysbio/syp030

Frajman B., Heidari N., Oxelman B. Phylogenetic relationships of Atocion and Viscaria (Sileneae, Caryophyllaceae) inferred from chloroplast, nuclear ribosomal, and low-copy gene DNA sequences. Taxon, 2009b, 58(3): 811-824.

Frajman B., Tholleson M., Oxelman B. Taxonomic revision of Atocion and Viscaria (Sileneae, Caryophyllaceae). Bot. J. Linn. Soc., 2013, 173: 194-210. https://doi. org/10.1111/boj.12090

Goertzen L.R., Cannone J.J., Gutell R.R., Jansen R.K. ITS secondary structure derived from comparative analysis: implications for sequence alignment and phylogeny of the Asteraceae. Mol. Phylogenet. Evol., 2003, 29: 216234. https://doi.org/10.1016/S1055-7903(03)00094-0

Gottschling M., Hilger H.H., Wolf M., Diane N. Secon-dary structure of the ITS1 transcript and its application in a reconstruction of the phylogeny of Boraginales. Plant Biology, 2001, 3: 629-636. https://doi. org/10.1055/s-2001-19371

Gottschling M., Plötner J. Secondary structure models of the nuclear internal transcribed spacer regions and $5.8 \mathrm{~S}$ $r$ RNA in Calcioidinelloideae (Peridiniaceae) and other dinoflagellates. Nucleic Acids Res., 2004, 32(1): 307-315. https://doi.org/10.1093/nar/gkh168

Gupta P.K., Roy J.K., Prasad M. Single nucleotide polymorphisms: A new paradigm for molecular marker technology and DNA polymorphism detection with emphasis on their use in plants. Curr. Sci., 2001, 80(4): 524-535.

Hall T.A. BioEdit: a user-friendly biological sequence alignment editor and analysis program for Windows 95/98/ NT. Nucleic Acids. Symp. Ser., 1999, 41: 95-98.

Hastings W.K. Monte Carlo sampling methods using Markov chains and their applications. Biometrika, 1970, 57: 97-109. https://doi.org/10.2307/2334940

Hodač L., Scheben A.P., Hojsgaard D., Paun O., Hörandl E. ITS polymorphisms shed light on hybrid evolution in apomictic plants: a case study on the Ranunculus auricomus complex. PLoS ONE, 2014, 9(7): e103003. https:// doi.org/10.1371/journal.pone.0103003

Hřibová E., Č́ižková J., Christelová P., Taudien S., Langhe E., Doležel J. The ITS1-5.8S-ITS2 sequence region in the Musaceae: structure, diversity and use in molecular phylogeny. PLoS ONE, 2011, 6(3): e17863. https://doi. org/10.1371/journal.pone.0017863

King R.C., Stansfield W.D., Mulligan P.K. A Dictionary of Genetics. $7^{\text {th }}$ ed. Oxford: Oxford Univ. Press, 2007, $608 \mathrm{pp}$.

Kunin V., Engelbrekston A., Ochman H., Hugenholz P. Wrinkles in the rare biosphere: pyrosequencing errors can lead to artificial inflation of diversity estimates. Environ. Microbiology, 2011, 12(1): 118-123. https://doi. org/10.1111/j.1462-2920.2009.02051.x

Klokov M.V. Silene. In: Flora URSR. Ed. M.I. Kotov. Kyiv: Vyd-vo Akad. nauk UkrRSR, 1952, vol. 4, pp. 523-553. [Клоков М.В. Silene. В кн.: Флора УРСР. Ред. М.I. Котов. Київ: Вид-во АН УРСР, 1952, т. 4, с. 523-553]. 
Liu J.S., Schardl C.L. A conserved sequence in internal transcribed spacer 1 of plant nuclear RNA genes. Plant Mol. Biol., 1994, 26(2): 775-778.

Martynyuk V.O., Karpenko N.I., Tsarenko O.M. Biol. Bull. of Melitopol State Pedagog. Univ., 2015, 5(1): 8-23. [Мартинюк В.О., Карпенко Н.I., Царенко О.М. Деякі мікроморфологічні особливості Atocion lithuanicum (Zapał.) Tzvel. та A. armeria (L.) Raf. флори України. Біол. вісн. МДПУ, 2015, 5(1): 8-23]. https:// doi.org/10.7905/bbmspu.v5i1.901

Martynyuk V.O., Tyshchenko O.V., Karpenko N.I., Tarieiev A.S., Kostikov I.Yu. Taxonomic status of Atocion hypanicum (Klokov) Tzvelev (Caryophyllaceae) inferred from analysis of ITS1 and ITS2 secondary structure. Chornomors'k. bot. z., 2014, 16(4): 416-425. http://doi. org/10.14255/2308-9628/14.104/1

Mau B., Newton M., Larget B. Bayesian phylogenetic inference via Markov chain Monte Carlo methods. Biometrics, 1999, 55(1): 1-12.

Merget B., Wolf M. A molecular phylogeny of Hypnales (Bryophyta) inferred from ITS2 sequence-structure data. BMC Research Notes, 2010, 320(3): 1-8. https://doi. org/10.1186 /1756-0500-3-320

Mikhaylova Y.V., Krapivskaya E.E., Rodionov A.V. Molecular phylogenetic study of Xamilensis Raf. recognized as the segregate genus in the Sileneae tribe. Russ. J. Genet., 2016, 6(2): 144-151. https://doi.org/10.1134/ S2079059716020052

Mosyakin S.L., Fedoronchuk M.M. Vascular plants of Ukraine. A nomenclatural checklist. Kiev, 1999, xxiii + 345 pp. https://doi.org/10.13140/2.1.2985.0409

Moysiyenko I.I., Tarieiev A.S., Didenko V.I., Karpenko N.I., Kostikov I.Yu. Centaurea breviceps Iljin (Asteraceae, Magnoliophyta): neotype and its annotation according to ITS1 and ITS2 secondary structures. Chornomors'k. bot. z., 2014, 10(3): 276-286. https://doi. org/10.14255/2308-9628/14.103/1

Müller T., Philippi N., Dandekar T., Schultz J., Wolf M. Distinguishing species. $R N A$, 2007, 13: 1469-1472. http://doi.org/10.1261/rna.617107

Niketić M., Stevanović V., Tomović G. Nomenclatural and taxonomic notes on the flora of Serbia and the Balkan Peninsula. I. Caryophyllaceae. Arch. of Biol. Sciences, 2007, 59(4): 387-396. https://doi.org/10.2298/ ABS0704387N

Oxelman B., Lidén M. Generic boundaries in the tribe Sileneae (Caryophyllaceae) as inferred from nuclear rDNA sequences. Taxon, 1995, 44: 525-542.

Oxelman B., Liden M., Rabeler R.K., Popp M. A revised generic classification of the tribe Sileneae (Caryophyllaceae). Nord. J. Bot., 2000, 20(6): 743-748.

Oxelman B., Rautenberg A., Thollesson M., Larsson A., Frajman B., Eggens F., Petri A., Aydin Z., Topel M., Brandtberg-Falkman A. Sileneae taxonomy and systematics. 2013. https://www. Sileneae.info. Accessed 14 July 2014.

Popp M., Oxelman B. Inferring the history of the polyploid Silene aegea (Caryophyllaceae) using plastid and homoeologous nuclear DNA sequences. Mol. Phylogen. Evol., 2001, 20(3): 478-481. https://doi. org/10.1006/mpev.2001.0977
Posada D., Crandall K.A. Modeltest: testing the model of DNA substitution. Bioinformatics, 1998, 14: 817-818.

Red Data Book of Lithuania. Ed. V. Rašomavičius. Kaunas: Lututë, 2007, 800 pp.

Ronquist F., Teslenko M., Mark P., Ayres D.L., Darling A., Höhna S., Larget B., Liu L., Suchard M.A., Huelsenbeck J.P. MRBAYES 3.2: Efficient Bayesian phylogenetic inference and model selection across a large model space. Syst. Biol., 2012, 61(3): 539-542. https://doi. org/10.1093/sysbio/sys029.

Ruhl M.W., Wolf M., Jenkins T.M. Compensatory base changes illuminate morphologically difficult taxonomy. Mol. Phylogenet. Evol., 2009, 7: 664-669. https://doi.org /10.1016/j.ympev.2009.07.036.

Tarieiev A.S., Girin A.I., Karpenko N.I., Tyshchenko O.V., Kostikov I.Yu. Chornomors'k. bot. z., 2011, 7(4): 309317. [Тарєєв А.C., Гірін А.I., Карпенко Н.I., Тищенко О.В., Костіков І.Ю. Модифікована методика виділення ДНК з гербарних зразків. Чорноморськ. бот. ж., 2011, 7(4): 309-317].

Tavaré S. Some probabilistic and statistical problems in the analysis of DNA sequences. In: Lectures on mathematics in the life sciences. Ed. R.M. Miura. Providence: Amer. Mathematical Soc., 1986, vol. 17, pp. 57-86.

Thompson J.D., Higgins D.G., Gibson T.J. CLUSTAL W: improving the sensitivity of progressive multiple sequence alignment through sequence weighting, position-specific gap penalties and weight matrix choice. Nucleic Acids Res., 1994, 22: 4673-4680.

Tzvelev N.N. De generibus tribus Sileneae DC. (Caryophyllaceae) in Europa Orientali. Novitates Systematicae Plantarum Vascularium, 2001, 33: 90-113. [Цвелев Н.Н. О родах трибы Смолевковых (Sileneae DC., Caryophyllaceae) в Восточной Европе. Новости системат. высш. раст., 2001, 33: 90-113].

Vaughn J.C., Sperbeck S., Ramsey W.J., Lawrence C.B. A universal model for the secondary structure of $5.8 \mathrm{~S}$ ribosomal RNA molecules, their contact sites with $28 \mathrm{~S}$ ribosomal RNAs, and their prokaryotic equivalent. Nucleic Acids Res., 1984, 12: 7479-7502.

White T.J., Bruns T., Lee S., Taylor J.W. Amplification and direct sequencing of fungal ribosomal RNA genes for phylogenetics. In: PCR protocols: a guide to methods and applications. Eds M.A. Innis, D.H. Gelfand, J.J. Sninsky, T.J. White. New York: Acad. Press, 1990, pp. 315-322.

Wiemers M., Keller A., Wolf M. ITS2 secondary structure improves phylogeny estimation in a radiation of blue butterflies of the subgenus Agrodiaetus (Lepidoptera: Lycaenidae: Polyommatus). BMC Evol. Biol., 2009, 9: 300. https://doi.org/10.1186/1471-2148-9-300

Yang Z., Rannala B. Bayesian phylogenetic inference using DNA sequences: a Markov chain Monte Carlo method. Mol. Biol. Evol., 1997, 14: 717-724.

Zapałowicz H. Conspectus florae Galiciae criticus / Krytyczny przeglad roślinności Galicyi. Krakow: Skład Głównyw Księgarni Spółki Wydaw. Polskiej, 1911, vol. 3, 175 pp.

Zuker M. Mfold web server for nucleic acid folding and hybridization prediction. Nucleic Acids Res., 2003, 31(13): 3406-3415.

Recommended for publication by S.L. Mosyakin 
Мартинюк В.O. ${ }^{1}$, Карпенко H.I. ${ }^{2}$, Тарєєв А.С. ${ }^{3}$, Костіков I.Ю. ${ }^{1}$ Відміни Atocion lithuanicum від A. armeria та їхнього гібриду (Sileneae, Caryophyllaceae) за ITS1ITS2-послідовностями та вторинними структурами їхніх транскриптів. Укр. бот. журн., 2018, 75(4): 322-334.

${ }^{1}$ Кафедра біології рослин, Навчально-науковий центр "Інститут біології та медицини", Київський національний університет імені Тараса Шевченка вул. Володимирська, 64, Київ 01004, Україна

${ }^{2}$ Науково-дослідна лабораторія "Біохімії, Навчальнонауковий центр "Інститут біології та медицини", Київський національний університет імені Тараса Шевченка вул. Володимирська, 64, Київ 01004, Україна

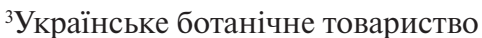

вул. Терещенківська, 2, Київ 01004, Україна

Багато видів рослин мають спірний таксономічний статус, уточнення якого є особливо важливим у випадку рідкісних таксонів, коли дискутується питання необхідності їхнього збереження. Одним із таких видів є Atocion lithuanicum - ендемічний таксон, який розглядають як самостійний вид або синонім A. armeria. Мета нашого дослідження полягала в уточненні таксономічного статусу A. lithuanicum з використанням молекулярно-філогенетичного аналізу та порівнянні моделей вторинних структур ITS1- та ITS2-послідовностей цих таксонів, а також їхнього гібриду. Результати філогенетичного аналізу з використанням Байєсівського підходу показали, що A. lithuanicum віддалений від $A$. armeria та є сестринським до A. compactum. При цьому філогенетичні взаємозв'язки на іншому дендриті, що включає гібриди та таксони 3 SNP, ще до кінця не з'ясовані. Натомість аналіз вторинних структур ITS1-послідовностей дозволив чітко розмежувати $A$. lithuanicum та $A$. armeria. Штучно створені гібриди F1 цих видів мають SNP у всіх сайтах, що розрізняють батьківські форми, і на реконструкціях моделей вторинних структур займають проміжне положення між ними. У подібних випадках SNP не можуть бути використані у філогенетичному аналізі. В той же час, у реконструкціях вторинних структур ITS1 та ITS2 SNP можуть бути використані як маркери гібридизаційних подій. За результатами проведених досліджень A. lithuanicum є caмостійним видом і не може розглядатися як синонім чи різновид $A$. armeria.

Ключові слова: Atocion lithuanicum, ендемізм, гібридизація, однонуклеотидний поліморфізм, філогенія
Мартынюк В.А. ${ }^{1,}$ Карпенко Н.И. ${ }^{2}$, Тареев А.С. ${ }^{3}$, Костиков И.Ю. ${ }^{1}$ Отличия Atocion lithuanicum от $\boldsymbol{A}$. armeria и их гибрида (Sileneae, Caryophyllaceae) по ITS1-ITS2последовательностям и вторичным структурам их транскриптов. Укр. бот. журн., 2018, 75(4): 322-334

${ }^{1}$ Кафедра биологии растений, Учебно-научный центр "Институт биологии и медицины", Киевский национальный университет имени Тараса Шевченко ул. Владимирская, 64, Киев 01004, Украина

${ }^{2}$ Научно-исследовательская лаборатория "Биохимии", Учебно-научный центр "Институт биологии и медицины", Киевский национальный университет имени Тараса Шевченко ул. Владимирская, 64, Киев 01004, Украина

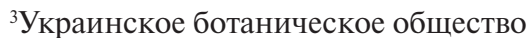
ул. Терещенковская, 2, Киев 01004, Украина

Многие виды растений имеют спорный таксономический статус, уточнение которого является особенно важным в случае редких таксонов, когда дискутируется вопрос о необходимости их сохранения. Один из таких видов - Atocion lithuanicum - эндемичный таксон, который рассматривают как самостоятельный вид или же синоним A. armeria. Цель нашего исследования заключалась в уточнении таксономического статуса A. lithuanicum c использованием молекулярно-филогенетического анализа и в сравнении моделей вторичных структур ITS1и ITS2-последовательностей этих таксонов, а также их гибрида. Результаты филогенетического анализа с использованием Байесовского подхода показали, что A. lithuanicum отдаленный от A. armeria и является ceстринским к $A$. compactum. При этом филогенетические отношения на другом дендрите, включающем гибриды и таксоны с SNP, еще до конца не выяснены. Вместе с тем, анализ вторичных структур ITS1-последовательностей позволил четко разграничить A. lithuanicum и A. armeria. Искусственно созданные гибриды F1 этих видов имеют SNP во всех сайтах, различающих родительские формы, и на реконструкциях моделей вторичных структур занимают промежуточное положение между ними. В подобных случаях SNP не могут использоваться в филогенетическом анализе. В то же время, в реконструкциях вторичных структур ITS1 и ITS2 SNP могут использоваться как маркеры гибридизационных событий. По итогам проведенных исследований $A$. lithuanicum является самостоятельным видом и не может рассматриваться как синоним или разновидность $A$. armeria.

Ключевые слова: Atocion lithuanicum, эндемизм, гибридизация, однонуклеотидный полиморфизм, филогения 